\title{
Extinction risk analysis of Anthocephalus macrophyllus in Gunungsewu Karst Area, Southern Java, Indonesia
}

\author{
LIES RAHAYU WIJAYANTI FAIDA, HERO MARHAENTO` \\ Faculty of Forestry, Universitas Gadjah Mada. Jl. Agro 1, Bulaksumur, Sleman 55281, Yogyakarta, Indonesia, Tel.: +62-274-550541, \\ vemail: marhaento@ugm.ac.id
}

Manuscript received: 22 April 2019. Revision accepted: 19 June 2019

\begin{abstract}
Faida LRW, Marhaento H. 2019. Extinction risk analysis of Anthocephalus macrophyllus in Gunungsewu Karst Area, Southern Java, Indonesia. Biodiversitas 20: 1897-1903. This paper aims to analyze the extinction risk of a local plant species namely Tebelo Pusoh or Jabon Merah (Anthocephalus macrophyllus) in Gunungsewu Karst Area (GKA), Southern Java, Indonesia. A. macrophyllus is a native species of GKA which its existence is currently being threatened by anthropogenic activities such as agricultural extension and housing development. To quantify the extinction risk of A. macrophyllus in GKA, an adapted equation from International Institute of Rural Reconstruction (IIRR) was used. Three extinction risk components namely hazard, vulnerability and coping capacity were assessed based on the local's perception. Hazard was defined as a source of potential threat to A. macrophyllus, vulnerability was a state of A. macrophyllus being exposed to damage, and coping capacity was efforts to reduce the potential damage of A. macrophyllus. Interviews with one hundred and ten respondents were conducted to assess the risk components. The Likert scale was used to analyze the interview results. The results showed that within the scale of 1 to 4 , the hazard score for A. macrophyllus was 2.67 , the vulnerability score was 1.67 , and the coping capacity score was 1.33 . Finally, it was estimated that the extinction risk of $A$. macrophyllus in GKA was 3.35 indicating a moderate level of extinction risk.
\end{abstract}

Keywords: Anthocephalus macrophyllus, extinction risk, Gunungsewu, karst, native species

\section{INTRODUCTION}

Gunungsewu, which means a thousand mountains, is the largest karst area in Java, Indonesia, covering about $1,300 \mathrm{~km}^{2}$ area with thousands of conical hills formed by tectonic setting, erosion, denudation and deposition since Miocene age. Large conical hills are well developed in places of higher altitudes, while small conical hills are predominant in the lower places (i.e., 15-20 meter above sea level (m.a.s.l). According to Haryono et al. (2016), limestone in Gunungsewu is composed of massive coralline limestone and bedded by chalky limestone with more than $650 \mathrm{~m}$ thickness. Kazuko (1995) found that the distribution pattern of cones seems to be strongly controlled by tectonic lines as lineaments and fault lines. Owing to its uniqueness, Gunungsewu Karst Area (GKA) was acknowledged by UNESCO, in 2015, as a part of Global Geopark Network (GGN).

Besides its physical uniqueness, GKA is rich in biodiversity. Field observations in just $20 \%$ area of GKA found that there were 66 species of plants, 32 species of aves, 18 species of mammals, and 23 species each of reptiles and amphibians (Matala Biogama 2002). Among the listed plants, many were cultivated annual crops in mixed garden areas, like Tectona grandis, Cocos nucifera, Parkia speciosa, Musa paradisiaca, Acacia auriculiformis, Gnetum gnemon, Albizzia falcata, and Anacardium occidentale, and cultivated seasonal crops in dry-land farms like Zea mays, Oryza spp., Manihot utilisima and Arachis hypogaea. As GKA is largely karst with caves, arthropods are the predominant faunal dwellers found in this area. Rahmadi (2008) found 11 species of triglobit and stigobit, but only four have been described. GKA is also the habitat for big mammals such as Panthera pardus, Hystrix javanica, Tupaia sp., Manis javanica, 2 species of Megachiroptera and 8 species of Microchiroptera, Cuon sp., Felis bengalensis and Macaca fascicularis (Atmaja and Dwisetyani 2015).

According to Haryono et al. (2008), biodiversity of GKA is threatened by increasing population pressure due to extensive cultivation that is currently reaching the tops of karst hills. Moreover, Kazuko (1995) reported that secondary forests cannot be found any more in GKA because lower cone hills with shallow soils are mostly occupied by terraced farmlands, while higher cone hills are afforested with plantations of teak and acacia, pushing the native species towards extinction. Preserving the native species in GKA, as in other local ecosystems, is crucial since they have been already adapted to a specific ecosystem, with well-established roles in the food chains and the recycling of materials (Sears 1993).

Faida (2012) found that at least twenty plant species are native species of GKA. These species are Asam Jawa (Tamarindus indica), Bintaos (Wrightia javanica), Bendo (Artocarpus elasticus), Bulu (Ficus elasticus), Dlingsem (Homalium tomentosum), Ilat-ilat (Ficus sp), Ipik (Ficus superba), Kepil (Nauclea subdita), Kepuh (Sterculia foetida), Kutu (Bridelia stipularis), Laban (Vitex pubescens), Lo (Ficus glumerata roxb.), Mojo (Feroniella lucida), Preh (Ficus ribes), Pulai (Alstonia scholaris), 
Rempelas (Ficus ampelas), Serut (Streblus asper), Talok (Grewia paniculata), Winong (Tetrameles nudiflora) and Tebelo Pusoh or Jabon Merah (Anthocephalus macrophyllus). These native species were randomly distributed within GKA and most of these plants have been abandoned and disposed by the local community.

Among the remaining native species of GKA, Anthocephalus macrophyllus (Tebelo Pusoh or Jabon Merah), belonging to the family Rubiaceae, is one of the most threatened species, the distribution of which is limited only to small areas of GKA (Faida 2012). According to Orwa et al. (2009), A. macrophyllus is a tropical tree species that is native to South Asia and Southeast Asia, including Indonesia. It is an early-succession species which grows best in the altitude range between 300 and 800 meters above sea level (m.a.s.l.), in warm temperature (i.e. an average of about $23^{\circ} \mathrm{C}$ ) and relatively wet weather with a mean annual rainfall of about $1,600 \mathrm{~mm} / \mathrm{year}$. $A$. macrophyllus grows well in deep and well-drained Entisols and is characterized by a large tree with a broad crown and straight cylindrical trunk. Tree height can reach 45 meters with trunk diameters up to $160 \mathrm{~cm}$ (Krisnawati et al. 2011). The bark color is gray with a smooth surface in young trees, but rough and longitudinally fissured in old trees. The leaves are broad glossy green with opposite leaf arrangement. Figure 1 shows the physical appearance of $A$. macrophyllus found in the study area. According to IUCN Redlist database (IUCN 2018), A. macrophyllus is in the list of Data Deficient species, meaning that information on the abundance and distribution of this species is not available for a proper assessment of conservation status. Thus, threats to the populations of A. macrophyllus are not well understood yet, requiring further study. In addition, $A$. macrophyllus has ecological and economic benefits. A. macrophyllus produces large amounts of litter to increase the soil organic carbon that can support soil health such as for improving nutrients for plants (Orwa et al. 2009). Besides the ecological benefits, A. macrophyllus has high economic value since it is good for ornamental use due to its wood characteristics that are easy to work with hand and machine tools. Thus, the conservation of this plant species is needed to support the local industry as well as the local traditions.

Rodrigues et al. (2006) argue that understanding the threat and the extinction risks of a species is a major step in biodiversity conservation. In addition, assigning the threat and extinction risk levels allow the identification of conservation priorities and improve the effectiveness of protected areas. In general, there are two ways to assess the extinction risk of a species: a modeling approach and a non-modeling approach (data-based approach). Benito et al. (2009) used modeling approach (i.e. species distribution model) to assess extinction-risk of endangered plant, namely Linaria nigricans in a Mediterranean landscape. They found that the model was able to simulate Linaria nigricans populations under the main threat of its existence that is greenhouses spreading. As an example of a nonmodeling approach, Cosiaux et al. (2018) investigated the extinction risk of palm flora in continental Africa, using global database of IUCN Red List Categories and Criteria. They found an overall low extinction risk for African palms in the immediate future, which is substantially lower than the global estimate. Similarly, Davies et al. (2011) used IUCN Red List database to identify the underlying drivers of extinction risk in plants on the Cape of South Africa.
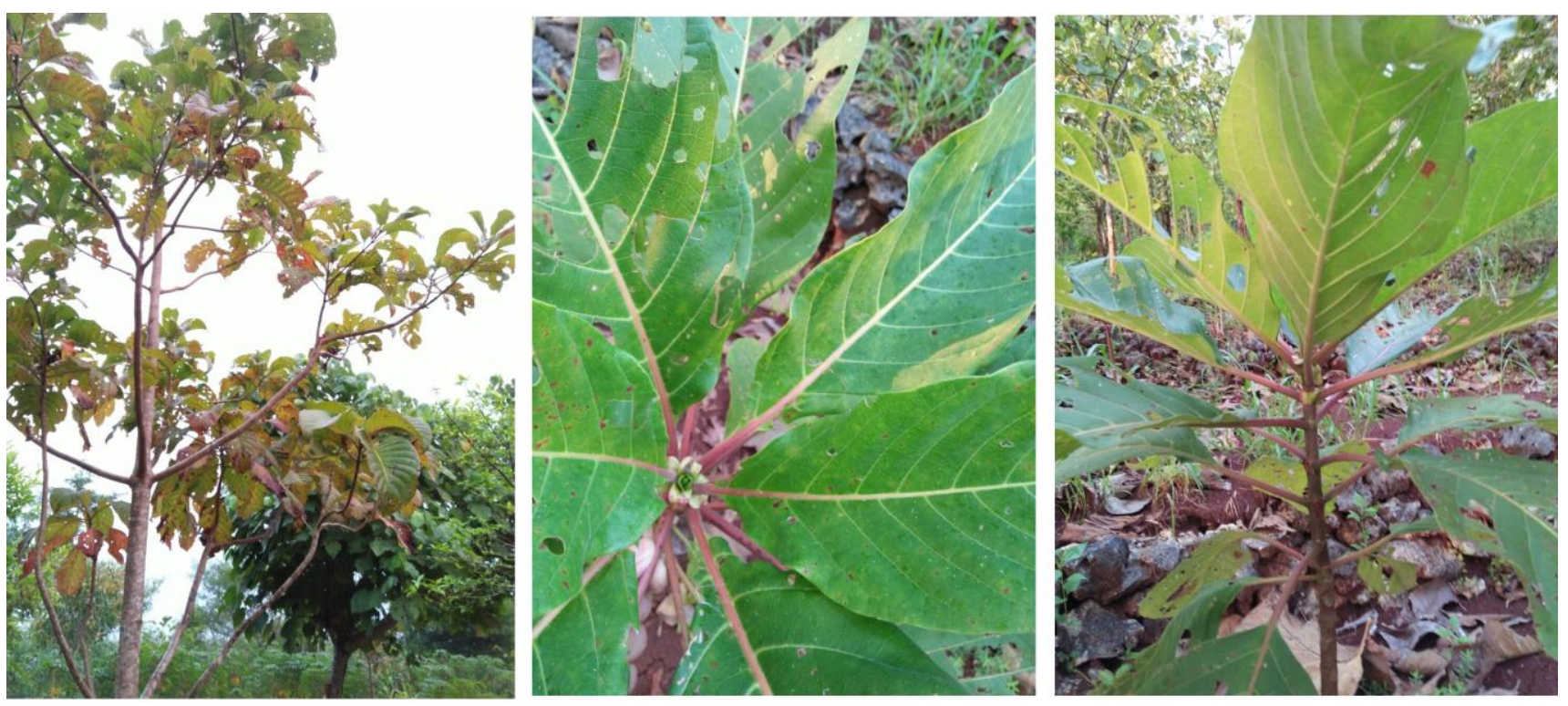

Figure 1. Tebelo Pusoh (Anthocephalus macrophyllus) in the field 
Here, we analyze the extinction risk of A. macrophyllus in Gunungsewu Karst Area, Indonesia. In this study, a nonmodeling approach using an adapted equation from the International Institute of Rural Reconstruction (IIRR) was used. Three extinction risk components namely hazard, vulnerability and coping capacity were assessed based on the local's perception. Interviews with local community were carried out to assess all those risk components. Specifically, the purposes of this study are: (i) to identify major and minor threats to A. macrophyllus in GKA based on literature review, field works, and local perceptions through interviews; (ii) quantify the extinction risks of $A$. macrophyllus in GKA using an equations adapted from IIRR; and (iii) propose measures to reduce the extinction risk.

\section{MATERIALS AND METHODS}

\section{Study area}

This study focusses on Jepitu village with a total area of $16.7 \mathrm{~km}^{2}$, part of Gunungsewu Karst Area (GKA) where Tebelo Pusoh or Jabon Merah (Anthocephalus macrophyllus) populations are present. This village is located in the south-eastern part of Gunungkidul district, Yogyakarta province, Indonesia, between $7.6-7.7^{\circ}$ southern latitude and $110.8-111.2^{\circ}$ eastern longitudes. The elevation range is between 200 and 250 m.a.s.l (see Figure 2). Slope $>15 \%$ occupies $77.5 \%$ of the study area. The study area is mainly occupied with lithosols and latosols type of soils with relatively thick soil depth (i.e. 24-120 cm). Jepitu village has tropical monsoon climate with a distinct wet season (November to April) and dry season (May to October). The mean daily temperature and annual rainfall are $25.5^{\circ} \mathrm{C}$ and $1,382 \mathrm{~mm}$, respectively. Each year, this area receives rainfall of about 89 days while the other days are relatively dry. According to the District Statistical Bureau (BPS 2017), the total population in Jepitu village is $\mathrm{s} 4,310$, with a population density of 258 inhabitants $/ \mathrm{km}^{2} .54 \%$ of the population is farmers and land use in the study area is predominantly dryland farming (e.g. rainfed rice and palawija crops) and mixed gardening with multipurpose trees like banana, soursop, and papaya.

\section{Data collection}

Data were collected from both primary and secondary sources. Primary data corresponds to aspects like plant distributions, social profile, social activities concerned with the utilization of A. macrophyllus, knowledge on plant and habitat characteristics of A. macrophyllus, and efforts to preserve A. macrophyllus. These primary data were acquired through interviews with farmers and public figures (e.g. village leaders) who were selected using snowball sampling technique. Snowball sampling technique is a nonprobability sampling method where the researchers used their own judgment to choose participants. According to Cohen and Arieli (2011), this technique is useful in conducting research in marginalized societies where a researcher may find difficulties in creating a representative sample of the research population. In the snowball sampling technique, two activities were carried out: identifying potential respondents in the population and then asking those subjects to suggest other people who can be the next respondents. In total, one hundred and ten respondents were interviewed where $92 \%$ of the respondents are farmers, $5 \%$ of the respondents were civil servants, and $3 \%$ of the respondents were others (i.e., driver and private teacher).

Sources of secondary data included population census, land use maps, house address and extent, and local regulations related to plant conservation. All these secondary data were obtained from all recorded files and reports from government offices such as District Statistical Bureau (BPS), National Land Administration Office (BPN), and District Plan and Development Bureau (Bappeda).

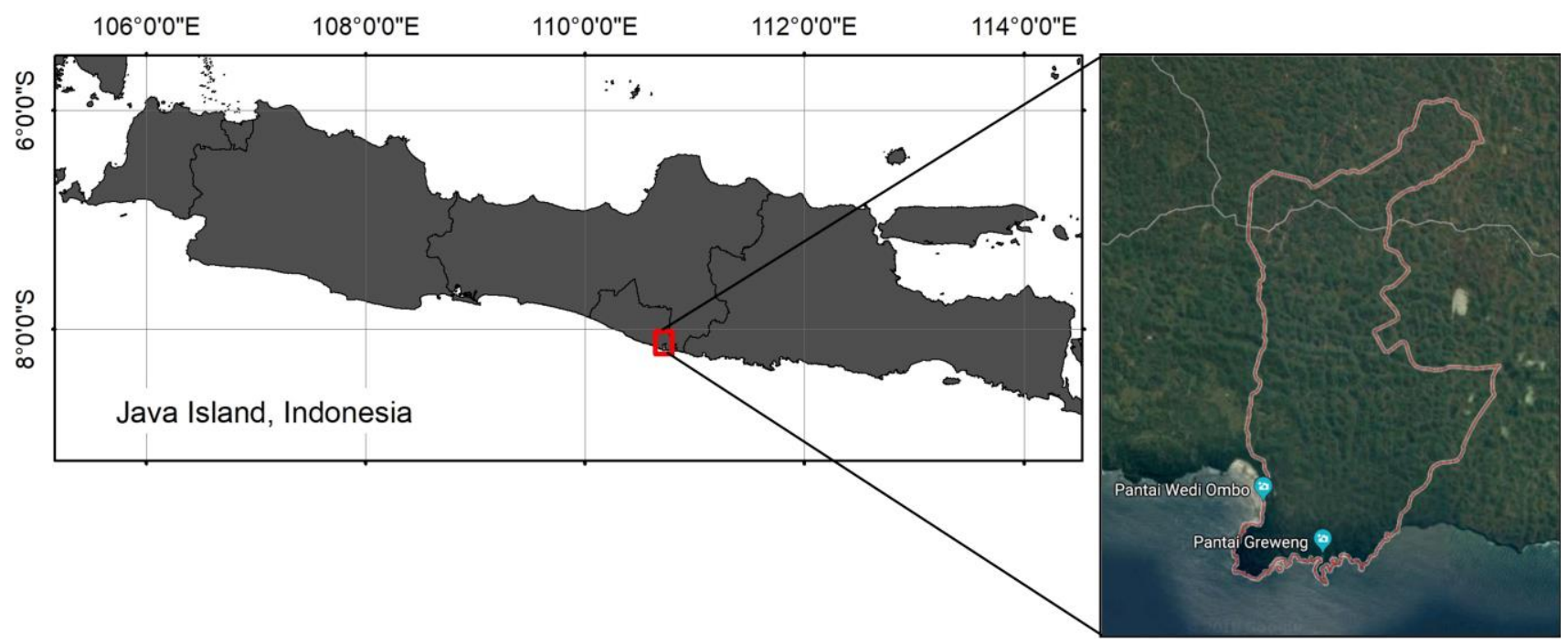

Figure 2. Administrative map of Jepitu Village in Gunungkidul District, Yogyakarta, Indonesia which is predominantly covered by conical karst 


\section{Plant extinction risk analysis}

We adapted the concept of risk analysis developed by the United Nations Disaster Relief Organization (UNDRO 1982) for plant extinction risk analysis of A. macrophyllus. Although the basic concepts of risk analysis were commonly used in the assessments of natural disaster risks (e.g. landslides, floods, and droughts), the application of risk analysis beyond natural disasters like ecological risks is greatly increasing (Stohlgren and Schnase 2006; Marhaento and Faida 2016). In this approach, to analyze the risk, three risk components were assessed namely hazard, vulnerability, and coping capacity. Following terminology from De León and Carlos (2006), hazard (H) was defined as "the probability or possibility that an external event manifests itself in a certain geographical area within a certain interval of time". Theoretically, hazard was caused by either natural event like earthquakes and volcanic eruptions or man-made event like industrial explosions and release of toxic chemicals. For this research, hazard was defined as a source of potential damage to A. macrophyllus. In addition, vulnerability (V) was defined as "conditions of incapacity to cope with disasters once they have taken place, which can span from the notion of the predisposition of a system to be affected or damaged by an external event at a certain instant of time to the notion as a residue of potential damages which cannot be targeted through the implementation of typical measures", while coping capacities (C) referred to "the means by which people or organizations use available resources and capacities to face adverse consequences related to a disaster". In this research, vulnerability was defined as a state of A. macrophyllus being exposed to damage according to the local perspective, while coping capacity was defined as efforts to reduce the potential damage of A. macrophyllus.

For each risk component, contributing factors were identified and classified based on Likert scale (Likert 1932). Likert scale is a technique of measuring attitudes by asking respondents a series of statements about a topic, in terms of the extent to which state they agree. Likert scale uses fixed choice response formats (i.e. levels of agreement or disagreement) and is designed to measure attitudes or opinions (Burns and Grove 1997). In this study, respondents were offered a choice of three pre-coded responses (i.e. agree, neither agree nor disagree, disagree). Furthermore, we regarded "agree" a high score of 3, "neither agree nor disagree" a moderate score of 2, and "disagree" a low score of 1 . Table 1 shows factors of each risk component to be answered by the respondents.

A mathematical expression for risk analysis based on those three components (i.e. hazard, vulnerability, and coping capacity) is adapted from the International Institute of Rural Reconstruction (IIRR and Cordaid 2013) and represented in an equation as follow.

Risk $=\frac{\text { Hazard } * \text { Vulnerabil ity }}{\text { Coping Capacity }} \ldots \ldots \ldots \ldots \ldots \ldots \ldots \ldots \ldots$ Eq. 1

By this equation, the extinction risk level of $A$. macrophyllus in a specific period of time is probabilistically determined as a function of hazard, vulnerability, and coping capacity. Combination between the Likert scale and risk function may result in a risk score range between 0.33 and 9 . By proportionally dividing the risk score range into three levels, we classified the risk level into three levels namely high extinction risk (i.e. Score $6.11 \leq 9$ ), moderate extinction risk (i.e. Score $3.22 \leq$ 6.1 ) and low extinction risk (i.e. Score $0.33 \leq 3.21$ ). High extinction risk is the extent to which the plant is at risk to locally disappear in the near future. Moderate extinction risk is the extent to which the plant remains at risk even when plant culture and plant conservation measures are in place. Low extinction risk is the extent to which the plant is abundant and no threats to its existence. In this research, for each extinction risk level, different risk mitigation scenarios were proposed.

Table 1. Factors contributed to extinction risk of Anthocephalus macrophyllus

\begin{tabular}{|c|c|c|}
\hline Risk components & Id & Factors \\
\hline \multirow[t]{6}{*}{ Hazard } & H1 & A. macrophyllus as a food source for cattle \\
\hline & $\mathrm{H} 2$ & A. macrophyllus as materials for domestic construction \\
\hline & $\mathrm{H} 3$ & A. macrophyllus is being cut during land clearance \\
\hline & $\mathrm{H} 4$ & A. macrophyllus has a good economic value \\
\hline & H5 & A. macrophyllus has less usage besides its wood \\
\hline & H6 & A. macrophyllus has low wood quality (i.e. wood strength and durability) \\
\hline \multirow[t]{3}{*}{ Vulnerability } & V1 & A. macrophyllus has slower growth rate than other local trees \\
\hline & $\mathrm{V} 2$ & A. macrophyllus is abundant and relatively easy to find \\
\hline & $\mathrm{V} 3$ & A. macrophyllus has good resistance to plant diseases \\
\hline \multirow[t]{3}{*}{ Coping Capacity } & $\mathrm{C} 1$ & Local community is willing to plant $A$. macrophyllus \\
\hline & $\mathrm{C} 2$ & Local community is willing to cultivate A. macrophyllus \\
\hline & $\mathrm{C} 3$ & Local community is willing to preserve A. macrophyllus \\
\hline
\end{tabular}




\section{RESULTS AND DISCUSSION}

\section{Results}

Six hazard factors of $A$. macrophyllus were assessed and resulted in a high level of hazard. As shown in Figure 3 , we found that all respondents used A. macrophyllus as a source of food for their cattle. Usually, the locals cut leaves including their small branches to directly feed their cattle (i.e. cows and goats). According to District Statistical Bureau (BPS 2017), the number of cattle owned by the local community has increased almost twofold in the past decade. Besides as a food source for cattle, the locals also use A. macrophyllus as a material for domestic construction. $81 \%$ of respondents agreed that $A$. macrophyllus can be utilized for wood carpentry, such as roof batten and house pillar. They argued that, in dry conditions, A. macrophyllus can produce good quality wood which can support small buildings (e.g. farmer huts). Although most of the respondent agreed that A. macrophyllus can be utilized for construction, they were of the opinion that A. macrophyllus has low economic value and only $22 \%$ of the respondents gave the opposite opinion. The majority of respondents argued that $A$. macrophyllus did not significantly contribute to their income since it has a slow-growth rate where, at age of 25 years, the wood circumference is only about $30-60 \mathrm{~cm}$. Thus, they prefer to plant other fast-growing crops like teak or acacia which has good market. For that reason, $A$. macrophyllus often being cut by farmers during the land clearance as they do not see it as an economically potential tree. Corroborative remarks were obtained from the interview results of factor $\mathrm{H} 6$ where almost $50 \%$ of respondents were doubtful about the wood quality of $A$. macrophyllus. Knowledge limitation about the wood characteristics was the main reason why the locals do not care about the existence of $A$. macrophyllus.
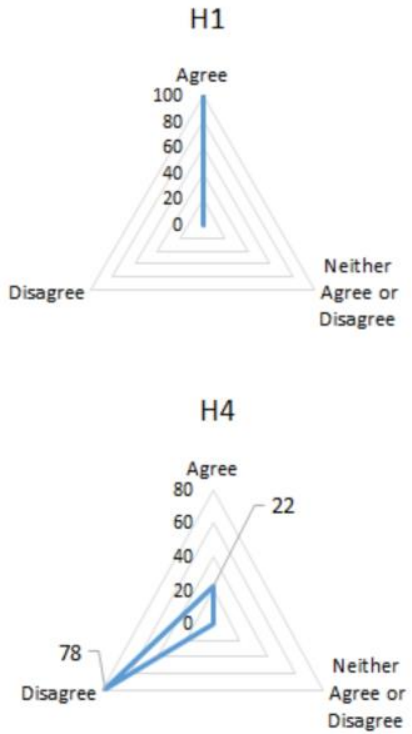

V1
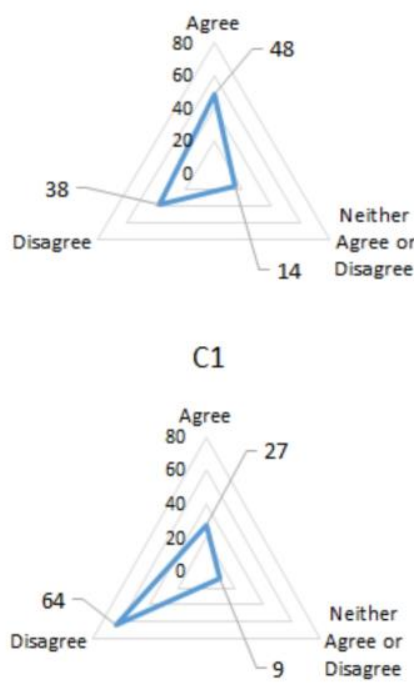

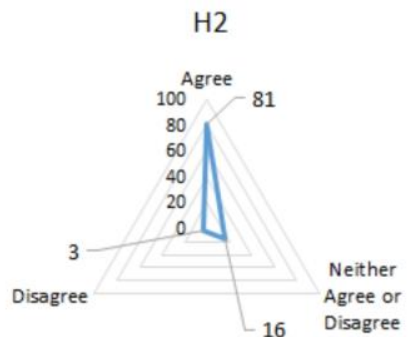

H5

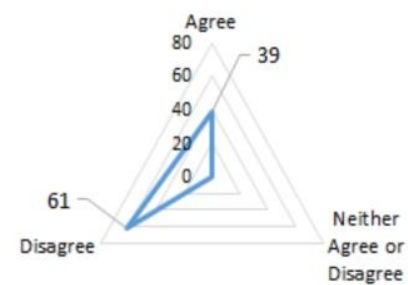

V2
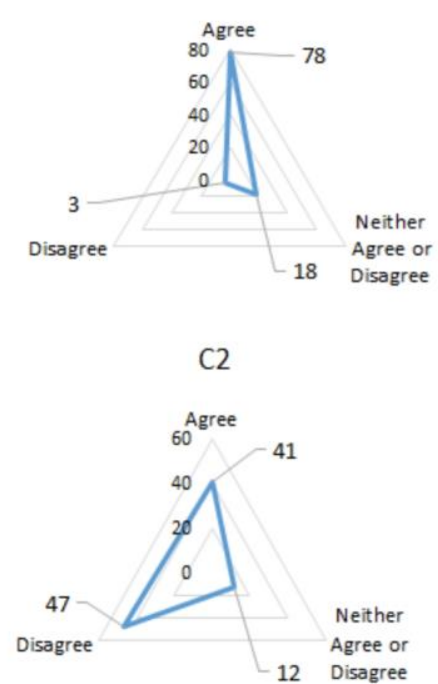

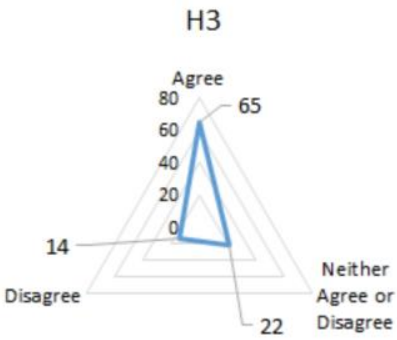

H6

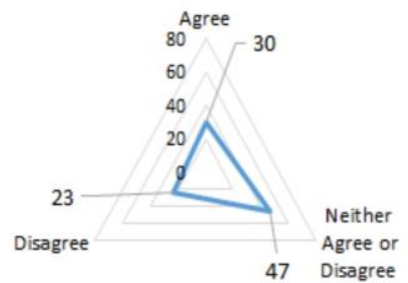

V3

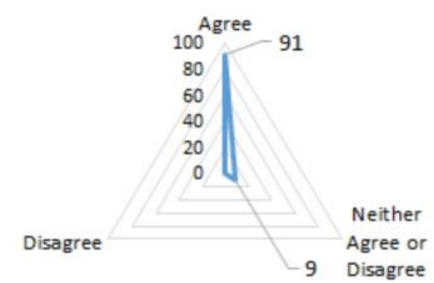

C3

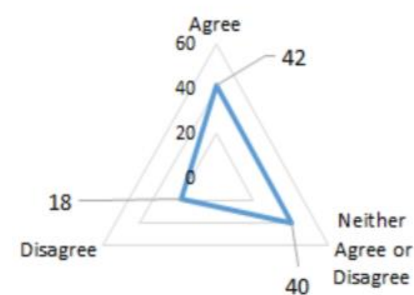

Figure 3. Local perception for each risk components based on Likert scale. Numbers are in percentage of the respondents 


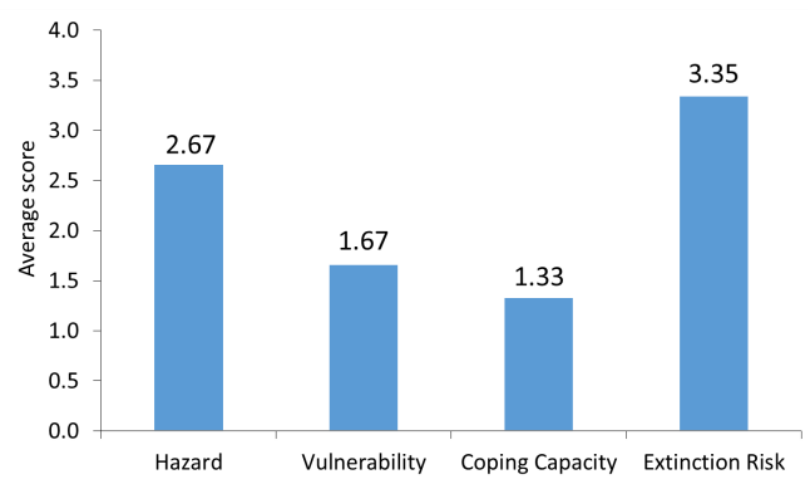

Figure 4. Hazards, vulnerability, coping capacity and extinction risk of Anthocephalus macrophyllus

Three factors regarding the vulnerability of $A$. macrophyllus were assessed which indicated a moderate level of vulnerability. Almost half of the respondents agreed that when compared to other economic plants like teak and acacia, A. macrophyllus has a slower growth rate and therefore the locals argued that A. macrophyllus was not economically promising. In addition, $78 \%$ of respondents could still find $A$. macrophyllus in their surroundings easily, which showed that the locals are less concerned about the existence of A. macrophyllus.

Despite the ability of $A$. macrophyllus to survive in harsh habitat conditions, efforts from the local community to reduce the potential damage was low which increases the extinction risk. We found that only $27 \%$ of respondents agreed to plant A. macrophyllus in their land. However, $42 \%$ of respondents were willing to cultivate the plant. The locals argued that they do not want to plant $A$. macrophyllus in their field because it has low economic value and therefore they prefer to plant other promising crops. However, if A. macrophyllus grows by itself in their land, they will take care of the plant as they need plant leaves for feeding their cattle. This condition actually implied that the locals are open to preserve $A$. macrophyllus.

Figure 4 shows the extinction risk score of $A$. macrophyllus that is in a moderate level of risk, with score of 3.35). A high score for hazards and a low score for coping capacity indicated that the existence of $A$. macrophyllus is threatened by the external factors, in particular, human activities. A rapid increase of population followed by expansion of agriculture area which has reached the tops of karst hills has increased the potential hazard to $A$. macrophyllus. In addition, the local community tends to replace A. macrophyllus with other more profitable and fast-growing crops like teak and acacia. Thus, currently, A. macrophyllus can be only found in the remote areas (i.e. very steep slope).

\section{Discussion}

It was found that $A$. macrophyllus in the study area was at a moderate extinction risk level where a high hazard score and a low coping capacity score were balanced by a low score of vulnerability. This implied that threats from external factors (i.e. human activities) were the main factor to place A. macrophyllus at the risk of local extinction. A rapid increase of population followed by expansion of agricultural area and cattle ownership has increased the extinction risk. In addition, low economic value of $A$. macrophyllus did not motivate the locals to cultivate the plant resulting in a massive decrease in number of this species in the study area. This study agrees with Haryono et al. (2008) and Kazuko (1995) that human activities are the major threat to the continued existence of native species in Gunungsewu Karst Area.

The plant characteristics were the main reason for the ability of $A$. macrophyllus to survive and exist in the study area that is characterized by a shallow soil with relatively dry condition. According to Krisnawati et al. (2011), A. macrophyllus is a fast-growth species with an ability to grow on a variety of soils under water scarce condition. In addition, no serious diseases have been reported attacking this species. This is also the main reason that this species can still be found easily within the study area, in particular, on the steep slope areas. Because of its high adaptability to various conditions, A. macrophyllus has relatively low score of vulnerability which has contributed to reduce the extinction risk level. However, it should be mentioned that in this research the vulnerability factors were assessed based on the local perception through interviews. The growth rate, plant distribution, and ability of plant to survive under environmental-stress conditions are ecological indicators that can be assessed by quantitative approaches like field measurement. For this reason, the vulnerability score might be a source of bias on the extinction risk level assessment.

In order to mitigate the extinction risk of $A$. macrophyllus, several measures can be adopted which basically aim to decrease the hazard and the vulnerability factors while the coping capacity factor is increased. For a proper assessment of conservation status, firstly, collecting more data about the ecology of A. macrophyllus in order to know its abundance and distribution is vital. With sufficient information about the conservation status of $A$. macrophyllus, ecological measures to mitigate the extinction risk can be carried out, both locally and globally. Secondly, knowledge of local community about the ecological and economic importance of A. macrophyllus has to be enhanced. According to Orwa et al. (2009), A. macrophyllus is suitable for reforestation and afforestation programs because it can help to improve physical and chemical properties of the soil due to its large amounts of leaf and non-leaf litter resulting in an increase in the level of soil organic carbon, cation exchange capacity, available plant nutrients and exchangeable bases. Besides the ecological benefits, A. macrophyllus has a high economic value since it is good for ornamental use due to its wood characteristics that are easy to work with hand and machine tools. In Bobung Village, about $25 \mathrm{~km}$ from Jepitu Village, A. macrophyllus is the main material for making traditional mask and handle of traditional Javanese weapon (keris). The wood artists argue that ornaments made from $A$. 
macrophyllus wood have better quality than Alstonia scholaris wood which is the most common material for making ornaments. This awareness about the ecological and economic benefits of $A$. macrophyllus is expected to motivate the local community to conserve A. macrophyllus. Finally, more attention from local and regional authorities to actively mitigate the extinction of $A$. macrophyllus is needed. It was observed during fieldwork that the local and regional authorities are not aware of any potential uses of A. macrophyllus. Thus, there is no intervention from their side to reduce the extinction rate of $A$. macrophyllus.

In conclusion, this study has assessed the extinction risk of a local plant species namely A. macrophyllus in Jepitu village, a part of Gunungsewu Karst Area, Indonesia. Using an adapted concept of risk analysis from The International Institute of Rural Reconstruction (IIRR), it was estimated that within the scale of 1-4, A. macrophyllus has a high hazard score of 2.67 , a moderate vulnerability score of 1.67 and a low coping capacity score of 1.33 , which resulted in a moderate level of extinction risk with a score of 3.35. A rapid increase of population followed by expansion of agriculture area and cattle ownership was the main reason for the moderate extinction risk of $A$. macrophyllus. In addition, because of its low economic value, the locals are not motivated to cultivate this plant resulting in decreasing of its number in Gunungsewu Karst Area, Indonesia.

\section{ACKNOWLEDGEMENTS}

The authors acknowledge the officials of Jepitu village office, District Statistical Bureau (BPS) Gunungkidul and District Plan and Development Bureau (Bappeda) of Yogyakarta province for providing the secondary data. We thank all respondents in Jepitu village for their willingness to support this research. Assistance provided by Asna Hayati during fieldwork and data analysis is especially acknowledged.

\section{REFERENCES}

Atmaja ED, Dwisetiyani B. 2015. Leopard (Panthera pardus 1.) in Purwodadi, Tepus, Gunungkidul, Yogyakarta, Indonesia. KnE Life Sci 2 (1): 567-573.

Benito BM, Martínez-Ortega MM, Muñoz LM, Lorite J, Peñas J. 2009. Assessing extinction-risk of endangered plants using species distribution models: a case study of habitat depletion caused by the spread of greenhouses. Biodivers Conserv 18 (9): 2509-2520.
BPS. 2017. Gunungkidul Regency in Numbers. Gunungkidul District Statistical Bureau, Indonesia.

Burns N, Grove SK. 1997. The Practice of Nursing Research Conduct, Critique, \& Utilization. W.B. Saunders and Co, Philadelphia.

Cohen N, Arieli T. 2011. Field research in conflict environments: Methodological challenges and snowball sampling. J Peace Res 48 (4): 423-435

Cosiaux A, Gardiner LM, Stauffer FW, Bachman SP, Sonké B, Baker WJ, Couvreur TL. 2018. Low extinction risk for an important plant resource: Conservation assessments of continental African palms (Arecaceae/Palmae). Biol Conserv 221: 323-333.

Davies TJ, Smith GF, Bellstedt DU, Boatwright JS, Bytebier B, Cowling RM, Forest F, Harmon LJ, Muasya AM, Schrire BD, Steenkamp Y. 2011. Extinction risk and diversification are linked in a plant biodiversity hotspot. PLoS Biol 9 (5): e1000620.

De León V, Carlos J. 2006. Vulnerability: a conceptional and methodological review. UNU-EHS, Bonn.

Faida LRW. 2012. Rekonstruksi hutan kawasan karst Gunungsewu (Forest reconstruction in Gunungsewu Karst Area). [Doctoral Thesis]. Universitas Gadjah Mada, Yogyakarta. [Indonesian]

Haryono E, Danardono D, Mulatsih S, Putro ST, Adji TN. 2016. The nature of carbon flux in Gunungsewu Karst, Java-Indonesia. Acta Carsol 45 (2): 173-185.

Haryono E, Susetyo JYE, Faida LRW. 2008. Dynamic Interrelationship Between Landform Evolutions, Human Habitation And Biodiversity In Gunungsewu Karst, Java-Indonesia. International Conference on Dynamic Interactions of Life and its Landscape Meeting of Young Researchers on Earth Sciences (MYRES) 2008, New Orleans, 20-23 May 2008.

IIRR \& Cordaid. 2013. Building resilient communities. A training manual on community managed disaster risk reduction. IIRR \& Cordaid, Philippines

IUCN. 2018. IUCN Red List of Threatened Species. Version 2018-1 <www.iucnredlist.org>.

Kazuko UY. 1995. Regionality of karst and the human activity in Gunungsewu, Java island. Acta Univ Szegediensis, 123, Hungary.

Krisnawati H, Kallio M, Kanninen M. 2011. Anthocephalus cadamba Miq.: Ecology, Silviculture and Productivity. CIFOR, Bogor.

Likert R. 1932. A Technique for the Measurement of Attitudes. Arch Psychol 140: 1-55.

Marhaento H, Faida LRW. 2016. Risiko kepunahan keanekaragaman hayati di Taman Nasional Gunung Merapi: Tinjauan Spasial. J Ilmu Kehutanan 9 (2): 75-84. [Indonesian]

Matala Biogama. 2002. Penelitian Flora dan Fauna di Kawasan Karst Kabupaten Wonogiri. Fakultas Biologi, UGM, Yogyakarta. [Indonesian]

Orwa C, Mutua A, Kindt R, Jamnadass R, Simons A. 2009. Agroforestree database: a tree species reference and selection guide version 4.0. World Agroforestry Centre ICRAF, Nairobi, KE.

Rahmadi C. 2008. Cave Fauna of Java. Project Report of Rufford Small Grants Foundation, Project REF: 40.11.06.

Rodrigues AS, Pilgrim JD, Lamoreux JF, Hoffmann M, Brooks TM. 2006. The value of the IUCN Red List for conservation. Trends Ecol Evol 21 (2): 71-76.

Sears AR. 1993. Native species planting guide for New York City and vicinity. Natural Resources Group, New York City.

Stohlgren TJ, Schnase JL. 2006. Risk analysis for biological hazards: what we need to know about invasive species. Risk Anal Intl J 26 (1): 163 173 .

UNDRO. 1982. Natural disasters and vulnerability analysis. Report of Expert Group Meeting. Office of The United Nations Disaster Relief Coordinator, Geneva. 